\title{
Beach ridges, foredunes or transgressive dunefields? Definitions and an examination of the Torres to Tramandaí barrier system, Southern Brazil
}

\author{
PATRICK A. HESP ${ }^{1}$, SERGIO R. DILLENBURG ${ }^{2}$, EDUARDO G. BARBOZA ${ }^{2}$ \\ LUIZ J. TOMAZELLI ${ }^{2}$, RICARDO N. AYUP-ZOUAIN ${ }^{2}$, LUCIANA S. ESTEVES ${ }^{3}$ \\ NELSON L.S. GRUBER ${ }^{2}$, ELIRIO E. TOLDO-Jr. ${ }^{2}$, LUIZ L.C. DE A. TABAJARA ${ }^{2}$ \\ and LUIZ C.P. CLEROT ${ }^{2}$ \\ ${ }^{1}$ Department of Geography and Anthropology, Louisiana State University \\ 227 Howe/Russell Geoscience Complex, Baton Rouge, LA 70803-4105, USA \\ ${ }^{2}$ Centro de Estudos de Geologia Costeira e Oceânica (CECO), Instituto de Geociências \\ Universidade Federal do Rio Grande do Sul, Av. Bento Gonçalves, 9500, Prédio 43125 \\ 291501-970 Porto Alegre, RS, Brasil \\ ${ }^{3}$ Fundação Universidade Federal do Rio Grande, Departamento de Geociências \\ Laboratório de Oceanografia Geológica, Cx. Postal 474, 96201-900 Rio Grande, RS, Brasil \\ Manuscript received on April 20, 2004; accepted for publication on November 24, 2004; \\ presented by LAURO V.S. NARDI
}

\begin{abstract}
Many prograded barriers and some dunefields in the world have been termed 'beach ridge' plains, but the actual genesis of the 'ridges' is often unknown. Use of the terms, berms, beach ridges and foredunes is also confusing in the literature because their definitions are highly variable and are commonly used interchangeably. Thus, the formation and definition of sand berms, beach ridges and foredunes is briefly reviewed. Beach ridges are re-defined as entirely wave formed deposits which are most commonly formed during high wave conditions and/or elevated water levels (e.g. storm surges). Foredunes are formed by aeolian sand deposition in vegetation on the backshore. Some dunefields in Brazil have been called beach ridge plains when they are, in fact, foredune plains, transgressive dunefields, or complex barriers (i.e. barriers comprising two types of dunes). The Holocene barrier extending from Torres to Tramandaí in southern Brazil has been regarded as a beach ridge plain. The landforms of this Holocene barrier comprise wide, relatively linear, widely spaced (400-600m), shore parallel ridges on the landward half, and more closely spaced (80-400m), lobate and crescentic, discrete ridges on the seaward half. Low, rolling dunefields, sand sheets, nebkha fields and deflation plains occur between the ridges. The barrier is re-interpreted as a prograded, transgressive dunefield barrier.
\end{abstract}

Key words: beach ridges, coastal barriers, transgressive dunefields, Holocene, southern Brazil.

\section{INTRODUCTION}

In Australia, the USA, Brazil, UK and many other countries, the term 'beach ridge' has often been used

Correspondence to: Patrick Hesp

E-mail: pahesp@1su.edu inter-changeably with 'foredune'. Some definitions actually describe both foredunes and beach ridges as the same landform. Foredune-like sand ridges have commonly been termed 'beach ridges' regardless of genetic origin, and the term 'beach ridge' has been 
commonly applied to sand ridges when the genesis of the ridge is actually unknown. Berms have also been termed beach ridges (Carter 1986). Recent attempts to review beach ridges either did not fully examine the confusion over use of terms in the literature, or the modes of origin (Taylor and Stone 1996), or argued for a very broad definition which even included cheniers (Otvos 2000). In southern Brazil, the landforms on barriers extending along the coast south of Torres have also been termed beach ridges (e.g. Delaney 1963, Godolphim 1983, Villwock 1984). This paper attempts to briefly examine the genesis and definitions of beach ridges and foredunes, and re-examines the origin of the dunes and dunefields of the Itapeva to Tramandaí region (Figure 1).

\section{DEFINITIONS OF BEACH RIDGES AND BERMS}

King (1972) indicates that beach ridges are equivalent to, or evolve into foredunes when she states that "sandy accretion features include beach ridges, which may become colonized, grow into coastal foredunes, and eventually become stabilized coastal dunes" (p. 424). Beach ridges have been defined by Stapor (1982) as "linear, mound-shaped ridges roughly paralleling the coast'" (p. 160). This definition is very broad and could apply to several ridge forms including berms and foredunes. Armstrong Price (1982) states that a beach ridge "may originate immediately back of the active beach as a flood-level ridge commonly of the coarser beach materials, or it may form as an aeolian accumulation caught in the vegetation immediately back of the beach proper" (p. 160; our emphasis). He further states that where excess amounts of sand are blown onto the ridge, it becomes a foredune. Thus, a beach ridge in his opinion can be either a water laid deposit or an aeolian deposit such as a foredune, or a combination of both. The general use of such a broad definition by Armstrong Price, King and others has meant that many studies of prograded barriers in the world refer to the ridges on such barriers as 'beach ridges' regardless of whether they are entirely aeolian de- posits (and commonly foredunes), entirely marine deposits, or a combination of both, and therefore we are left with little understanding of the genesis of the ridges.

Definitions and use of the terms 'berm' and 'beach ridge' have also been confusing in the literature, and the terms have at times been used interchangeably. For example, King (1972) states that "sandy ridges can form as a berm at the back of a beach either where it abuts against a solid rock coast, or where it lies against a low drift coast, or on a barrier island..." (p. 424; our italics). Viles (1988a, p. 47) defines a berm as "a ridge of sand parallel to the coastline, commonly found on the landward side of steeply sloping beaches". She states that it is a nearly horizontal feature formed by deposition at the upper limit of the swash zone. In defining beach ridges, she states that they are "accumulations of sediment forming a prominent feature on many beaches" and can take a variety of forms: "Ridges may be formed near the top of shingle or sandy beaches (in sand these are called berms)", (Viles 1988b, p. 45), and, "Ridges may also be formed in association with runnels near low tide level on shallow gradient beaches" (Viles 1988a, p. 45). King also describes ridge and runnel forms as beach ridges, and indicates that the uppermost, landward ridge may eventually evolve into a foredune (p. 434). These definitions appear to include berms, beach ridges, "sandy ridges", " "prominent features" and intertidal ridge and runnel systems as the same landform.

Otvos (2000) states that beach ridges are "relict, semiparallel, multiple ridges, either of wave (berm ridge) or wind (multiple backshore foredune) origin." (p. 84). He further regards cheniers as a special category of beach ridges (p. 83). Thus, he combines berm, beach ridge, chenier and foredune into one type.

\section{SAND BEACH RIDGE FORMATION}

The following primarily examines beach ridges formed in sand sized sediment, and does not deal 
I

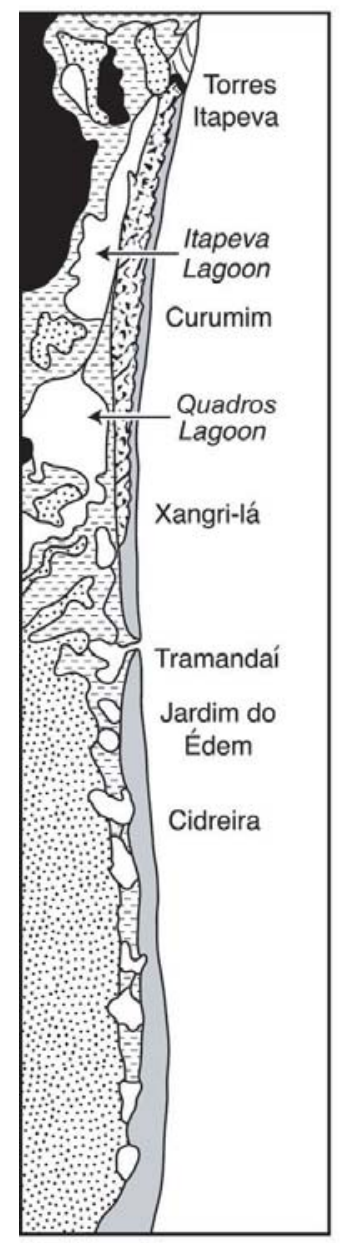

Bedrock

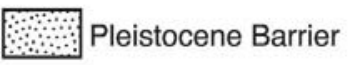

Holocene Lagoonal Deposits
II
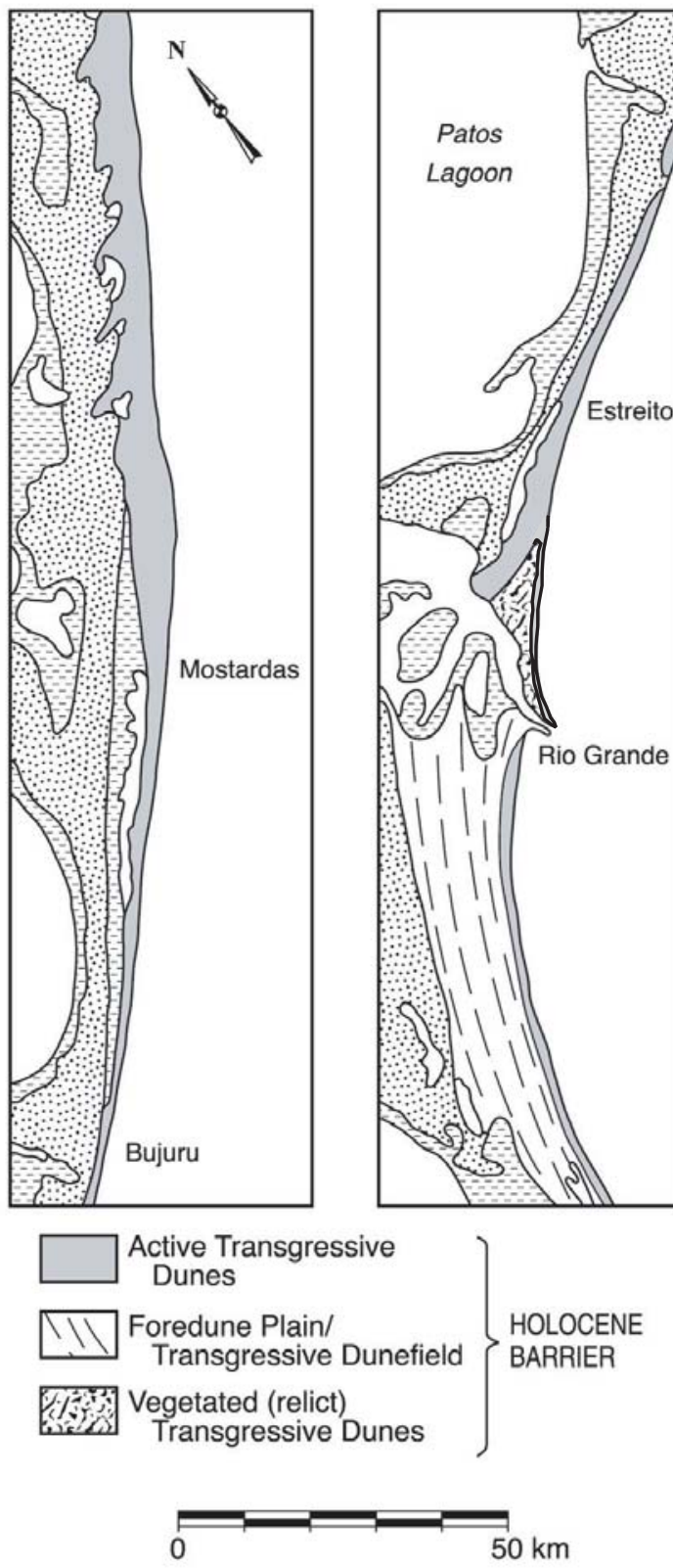

III
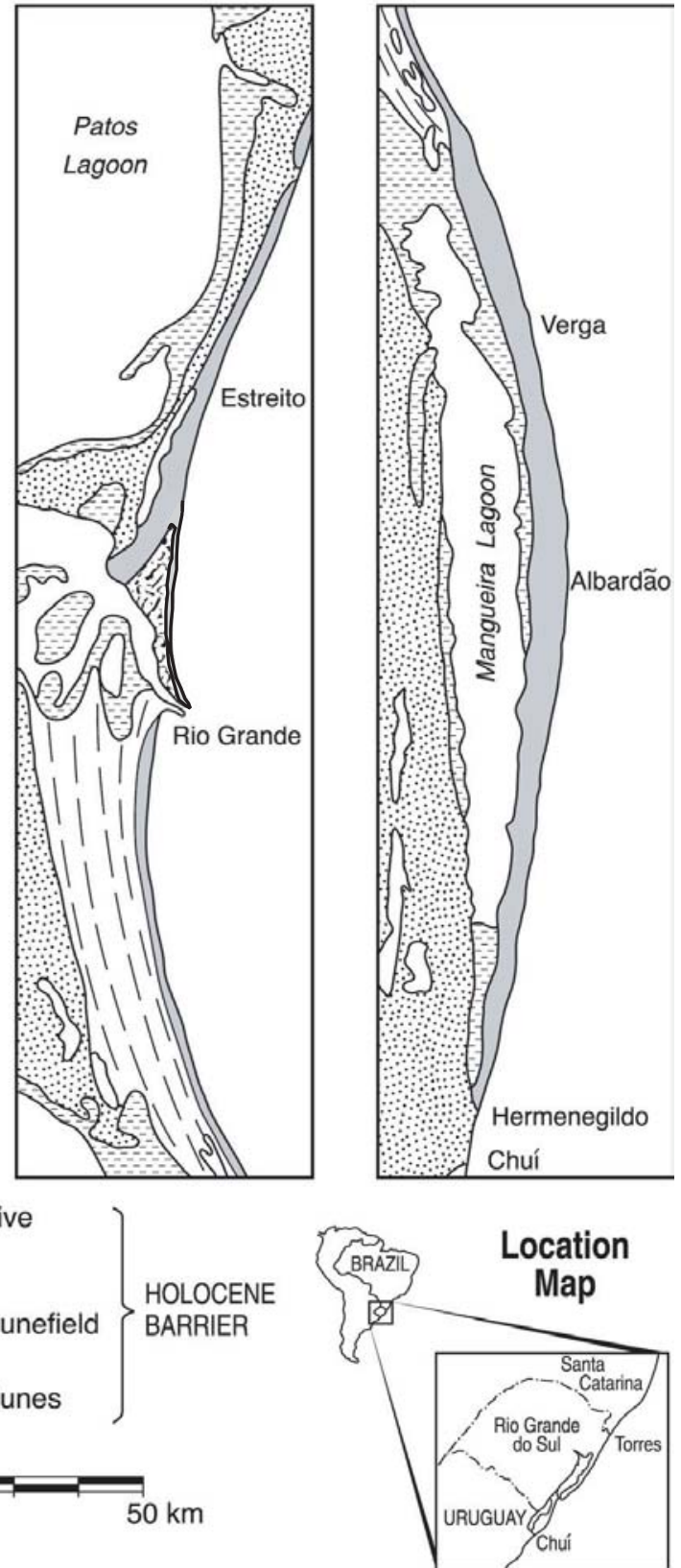

Fig. 1 - Pleistocene and Holocene barriers along the southern Brazilian coast from Torres to Chui. The first map (I) displays the northernmost sector and II, III, and IV the progressively more southern sectors. Barrier types are indicated for the Holocene barrier. This re-interpretation of the Dillenburg et al. (2000) figure indicates that the barrier system comprises relict (vegetated) transgressive dunefields, active transgressive dunefields, or a complex barrier type comprising both foredune ridges and transgressive dunefields.

with beach ridges (sensu stricto) formed of coarser material (Redman 1864, Johnson 1919, Guilcher 1958), or ridges which have formed as gravel or cobble beach ridges and been capped by later foredune development (beach-foredune ridges; see Hesp 1999).

\section{Formation BY WAVES}

Sand beach ridges may be formed during storm wave and elevated water level events (e.g. Psuty 1965), particularly on modally low energy beaches. Ul'st (1957), Stapor (1982) and others (e.g. Tanner 
and Stapor 1971, 1972) emphasized the predominance of marine processes in the formation of beach ridges. Tanner and Stapor $(1971,1972)$ argued that swash processes were most important and ridge construction occurred by berm formation during calm, not storm conditions (cf. Curray et al. 1969).

Sand beach ridges do form during storm wave events. Low beach ridges have been observed forming by swash action on the landward-most backshore of estuarine beaches during elevated water level and storm wave events in New South Wales, Australia and Western Australia (Hesp, pers. obs.). Similar sand beach ridges have formed on the shores of lagoons in Rio Grande do Sul (some have an aeolian capping) (Figure 2a,b) and in the landward half of the Tijucas (SC) beach ridge-chenier, complex, prograded barrier ("complex" - where two different basic types occur together; Brookfield 1992).

Curray et al. (1969) state that the primary beach ridge form is formed from emerged bars which accrete during low wave energy conditions. Komar (1976) indicates that sand beach ridges may form from emerged bars, although the latter would normally accrete onto the beach face and become berms, not beach ridges (see Hine 1979). Carter (1986) describes surfzone bars welding on to the beach face and terms these beach ridges. Most definitions would not include welding and attached intertidal bars or berms as beach ridges because they are not permanent features, and, in Carter's (1986) examples, the sand comprising the 'ridge' is rapidly deflated and removed downwind by aeolian transport to be incorporated into a foredune.

\section{Formation by Aeolian Processes}

Table I indicates a range of "beach ridge" construction hypotheses or studies related to aeolian genesis in addition to those presented above.

In the Australian and north American literature, the term 'beach ridge' was generally, and, in many cases, still is utilized to describe a relict foredune, and beach ridges to describe a foredune plain (i.e. a suite of two or more sand ridges formed originally as foredunes; see Hesp 1983, 1999, 2000 for reviews). In the authors' opinion, the confusion resulted, in part, because (i) there had been little detailed morphodynamic research conducted on foredune evolution and dynamics, and on foredune plains prior to the 1970's; (ii) the geological fraternity had referred (and commonly still does refer) to all shore parallel ridges and series of ridges as "beach ridges" regardless of an aeolian or wavebuilt origin (i.e. irrespective of genesis); (iii) some of the first work on, and definitions of beach ridges was conducted in the UK where the 'classic' beach ridges are gravel and cobble storm ridges (e.g. Redman 1864); (iv) some of the first Australian research and discussion on "beach ridge" evolution was carried out by researchers trained in the United Kingdom (e.g. Bird 1976, Davies 1957) where storm dominated, wave-built gravel, and mixed sand and gravel beaches and beach ridges (sensu stricto) were common; (v) beach ridge plains and foredune plains often look alike on aerial photography, particularly large scale photography, and are therefore easily confused; and (vi) researchers were struggling to explain how the ridges could be formed parallel to the coastline without being strongly formed or controlled by wave processes, and how swales formed.

Hesp (1983, 1984a, b, 1999) has shown that foredunes form by plant colonization of the backshore in various ways (seedling development, rhizomes and stolons growing onto the beach). Studies show that the crests of berms are never successfully colonized by pioneer plant seedlings, because the majority of the crest is almost always inundated (and often eroded) during spring tides and storm events, if the berm is not elevated above the maximum spring tide level. Even where surfzone sand bars emerge as spits or berms, the bars or berms must be above normal spring tide inundation levels to be successfully colonized by vegetation (Hine 1979). Swales develop as low aeolian deposition zones as the seaward portions of incipient foredunes trap most incoming sand and build up over time. Beach 'cut' or wind erosion of swales as preferred by Bird (2000) is unnecessary, and uncommon for swale construction and development. 


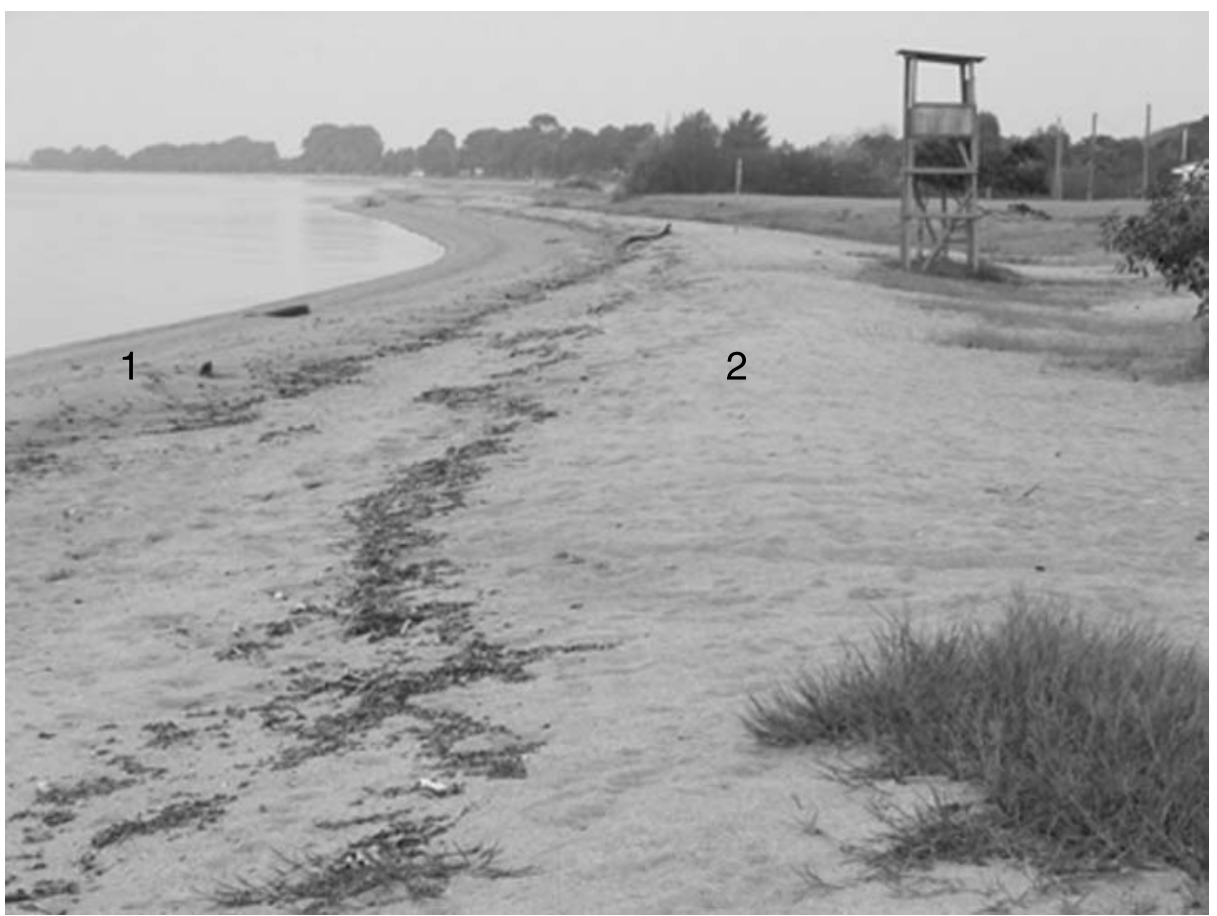

Fig. 2a-Active, modern berm ( 1 - near the water) and beach ridge ( 2 - center of photograph) forming on the Patos Lagoon at Arambare, Rio Grande do Sul. The berm is eroded, accreted, re-formed or destroyed by swash operating at various lake levels, and largely destroyed during high water level storm events (i.e. it is generally non-persistent). The beach ridge is formed at high water levels during storms and higher wave energy events by swash and is generally persistent.

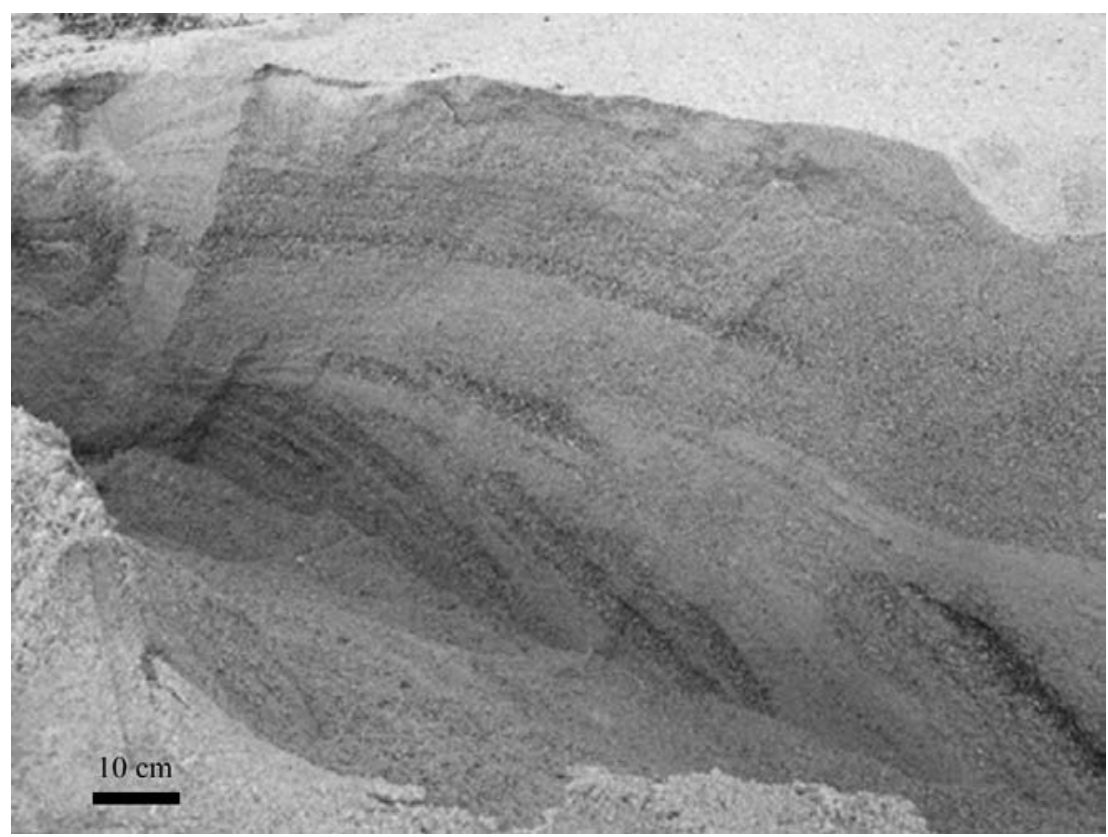

Fig. $2 b$ - Internal sedimentary structures within the crest of the beach ridge shown in figure 2a. All sediments are wave deposited backset, topset and foreset beds formed during high water level swash events. 
TABLE I

Some of the hypotheses and data for the initiation of sand "beach ridges" (so-called) and foredunes (apart from Otvos, and excluding wave-formed beach ridges). It may be seen that most sand "beach ridges" in this list are, in fact, foredunes formed by aeolian sand deposition in vegetation on the backshore.

\begin{tabular}{|c|c|}
\hline Author/Date & Proposed genesis of "beach ridges" \\
\hline Davies 1957 & $\begin{array}{l}\text { Formation of a berm, plant colonisation of berm, aeolian sand trapping and } \\
\text { formation of a ridge. Swales form between successive berms ('cut and } \\
\text { fill' hypothesis). }\end{array}$ \\
\hline McKenzie 1958 & $\begin{array}{l}\text { Incipient foredunes ("beach ridges") form where pioneer vegetation grows } \\
\text { seaward from a landward source trapping aeolian sand and eventually } \\
\text { forms a ridge. }\end{array}$ \\
\hline Bird 1960, 1976, 2000 & $\begin{array}{l}\text { Foredune forms on top of a berm and is scarped by storm waves. Waves } \\
\text { build a new berm in front and this is separated from the foredune by a low- } \\
\text { lying trough or swale. Dune grasses colonise the berm crest, swale is } \\
\text { unvegetated, and a new foredune is formed. It is the effect of beach cut } \\
\text { which separates dunes into parallel ridges; in the absence of cut, a foredune } \\
\text { became broadened as a coastal terrace (modified "cut and fill" hypothesis). }\end{array}$ \\
\hline Curray et al. 1969 & $\begin{array}{l}\text { Longshore bar is built upwards and emerges above sea level during low } \\
\text { wave conditions. Bar enlarges, becomes beach ridge. Dunes form on } \\
\text { top of the ridge. }\end{array}$ \\
\hline Hesp 1983 & $\begin{array}{l}\text { Incipient foredunes form by aeolian sand trapping in pioneer vegetation } \\
\text { on the backshore above the high spring tide mark. Australian "beach ridges" } \\
\text { of Davies and Bird are, in fact, foredunes. 'Cut' is unnecessary for formation } \\
\text { Swales develop as low deposition zones. }\end{array}$ \\
\hline Hesp 1984a, b & $\begin{array}{l}40 \text { year study at Cervantes shows that even under conditions of extreme } \\
\text { progradation }(\sim 13 \mathrm{~m} / \text { year) on a modal reflective beach, berms are not } \\
\text { colonised by vegetation; the backshore is. Multiple foredunes, regularly } \\
\text { spaced, symmetrical, linear, and shore parallel are formed with } \\
\text { intervening swales. }\end{array}$ \\
\hline Hesp 1999 & $\begin{array}{l}\text { Modal dissipative beaches do not display berms, yet have incipient fore- } \\
\text { dunes, established foredunes and foredune plains. The beaches are } \\
\text { characterised by linear to concave slopes; berms (and beach ridges) are } \\
\text { absent. The presence of a berm is therefore not a necessary pre-requisite for } \\
\text { foredune, or beach ridge (sensu stricto) formation. }\end{array}$ \\
\hline Otvos 2000 & Ridge is formed by wave or wind processes. \\
\hline
\end{tabular}

It is not necessary to invoke a berm or beach ridge nucleus or initiation (Bird 1960) to explain the regular, parallel nature of 'beach ridges' or foredunes (Fig. 3). Where a foredune is initiated by seeds deposited on, and then germinating and growing within a wrack or swash line on the backshore (not the berm crest), the seedlings are most commonly at the height of spring tide swash. They are thus aligned conformably with the beach outline (or plan shape) and direction of prevailing swell. Where the foredune is initiated by rhizome/stolon or shoot growth, or where seeds are scattered across 


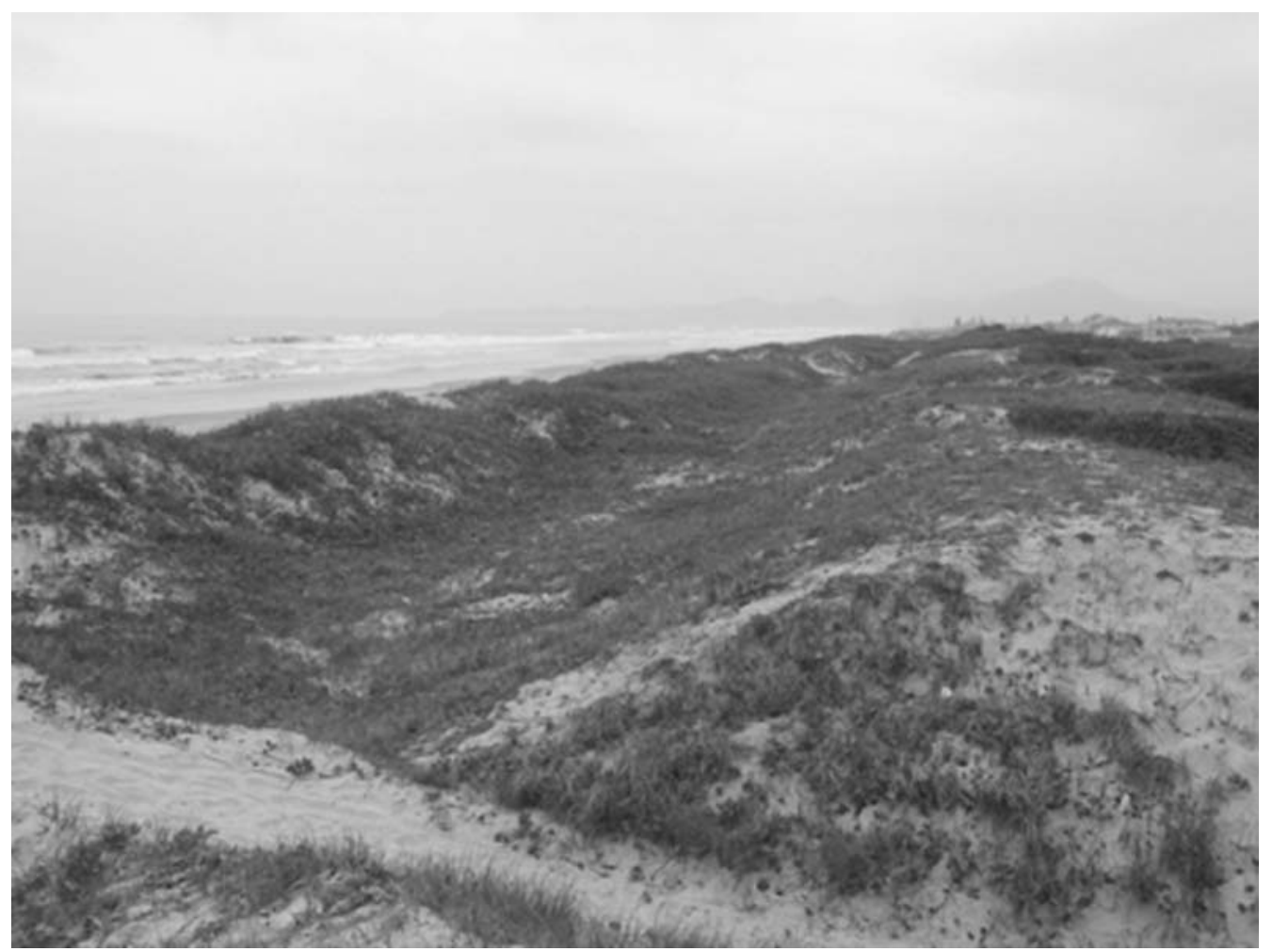

Fig. 3 - Navegantes foredune plain. The active foredune is on the left and separated from the next relict foredune ridge (center of photograph) by a swale. The distance from foredune crest to relict foredune crest varies from approximately 20 to $15 \mathrm{~m}$. Note the parallel lines of foredune ridges separated by swales, and the narrow distance between ridge crests. All ridges and swales have formed by aeolian sand deposition in vegetation on a prograding dissipative backshore.

the backshore by winds, the seaward extent of vegetative growth is controlled by spring tide swash and storm wave inundation (Davies 1980, Hesp 1984a, b). It is the occasional wave swash event, or wave scarping of the foredune on the uppermost backshore that either (i) restricts seaward growth of plants, (ii) forms a shore parallel edge to the vegetation by killing any plants that grow across the spring tide or storm water line, and/or (iii) trims or scarps the foredune and aligns it with the beach plan shape (Hesp 2002).

Discussions with several USA scientists indicate that they believe foredunes have to have a beach ridge at the base in order for regularly spaced, shore parallel, long, linear sand ridges to exist. However, temporal surveys of foredune initiation and development seldom indicate that beach ridge construction takes place (e.g. Hesp 1983, 1984b, 1999), and the formation of a beach ridge is not a necessary precursor for the development of parallel, regularly spaced, symmetrical to asymmetrical sand ridges (although it does occur in some conditions). Of course, waves may sometimes wash across part of the stoss face of a foredune, and may leave a few wave deposited laminae, but the majority of the sediments are normally aeolian in origin.

These statements are strongly supported by international evidence on the origin and genesis of foredunes (e.g. Salisbury 1952, Olson 1958, Sarre 1989, Law and Davidson-Arnott 1990, Carter and Wilson 1990, Ruz and Allard 1994, Angulo 1993, Hesp 2000).

\section{'BEACH RIDGES' OR FOREDUNES?}

The incipient foredune ridges monitored and described by various authors (e.g. McKenzie 1958, 
Hesp 1983, 1984b, Sarre 1989) are exactly the same types of ridges discussed by Davies, Bird and many of the other authors noted above. That is, most of the sand 'beach ridges' typical of the open ocean, wave dominated Australian, USA and some Brazilian coasts (e.g. Thom et al. 1981, Godolphin 1985) are, in fact, formed as foredunes, by the deposition of aeolian sand in vegetation on the backshore. Thus, they should not be called beach ridges, because their genesis is via aeolian processes.

\section{RE-DEFINING BEACH Ridges AND}

\section{Definitions of Berm ANd Foredune}

The discussion above indicates that there is considerable confusion in the literature regarding the terminology of berms and beach ridges, and the formation of beach ridges versus foredunes. We believe that beach ridges should be clearly morphodynamically and genetically distinguished from berms and foredunes.

Beach ridges are here re-defined as swash aligned, swash and storm wave built deposits or ridges formed primarily of sand, pebbles, cobbles (gravel) or boulders, or a combination of these sediments (Hesp 1999). They are typically formed at, or above the normal spring high tide level (King 1972). Clearly they may also contain various amounts of other marine sediments (e.g. wood, shell, pumice etc). They are purely or principally marine deposits formed by wave action. We believe that this definition should be regarded as the strict sense (sensu stricto) definition in the future. The classic beach ridges are the storm built shingle and cobble ridges such as those at Dungeness and Chesil Beach, U.K. (see King 1972, p. 422), but, as noted above, sand beach ridges occur in coarse to fine sand on some modally low energy beaches (open coast, lagoon or estuary; Figure 2a). Beach ridges have internal sedimentary structures typified by steep foresets (Figure $2 b)$.

A berm is here defined as a shore parallel, nonpersistent, wave built ridge or terrace formed at the limit of swash runup (Hesp 1999). It may be formed at all tide levels on a beach, but the crest is commonly formed at, or slightly above high tide level (King 1972). Berms commonly display a terrace form with a seaward swash slope or beach face (a 'riser' in fluvial terrace terminology), a marked break of slope at the berm crest and a linear, concave or convex berm top (or 'tread' in fluvial geomorphology). The berm 'crest' is the point or morphological break of slope where the riser meets the tread. The term, berm 'crest', should refer only to the point of break of slope, not the entire berm terrace tread surface. Every high tide may alter a berm to some degree, and storms may erode or destroy berms. Berms do not generally form on beaches such as modal dissipative beaches and some high energy intermediate beaches which display linear to slightly concave backshore and beach profiles, with or without ridge and runnel forms in microtidal to macro-tidal beach environments (Masselink and Short 1993, Short 1999). Berms display low to relatively high angle bedding structures on the berm (beach) face depending on surfzone-beach type, and very low angle, almost horizontally laminated structures on the backshore (Reineck and Singh 1986). These low angle, backshore beds may be preserved as a beach progrades and foredunes form over the top of the former backshore.

The critical difference between a berm and a beach ridge is that berms are generally not persistent forming part of the intertidal to slightly above high tidal active swept prism. Beach ridges (sensu stricto) typically form above the normal high spring tide level on open ocean beaches or mean water level in lagoons and estuaries and are generally persistent (Fig. 2a).

Foredunes are genetically and morphodynamically distinct from beach ridges. Foredunes are typically the foremost vegetated sand dune formed on the backshore zone of beaches by aeolian sand deposition within vegetation. They are generally shore-parallel, vegetated, ramps, terraces and convex ridges separated by concave swales (Hesp 1999). However, note that not all foremost dunes on the backshore are foredunes, since other dune types may occupy a foremost position especially on 
eroding coasts (Hesp 2002). Foredunes tend to display long, low angle, convex sedimentary structures when formed in moderate to high density vegetation and are distinct from beach ridges (see Hesp 1983).

\section{THE ITAPEVA TO TRAMANDAÍ BARRIER}

\section{Regional SetTing}

Rio Grande do Sul has a low-relief coastal plain formed during the Quaternary by juxtaposition of sedimentary deposits of four barrier/lagoon systems designated I (oldest) to IV (youngest) by Villwock et al. (1986). The coastal plain ranges from 20 to $80 \mathrm{~km}$ wide and is bordered landward by bedrock highlands. Climate is humid temperate with generally warm to hot temperatures in summer and cool temperatures in winter. Rainfall ranges from 1000 to $1500 \mathrm{~mm}$ and is evenly distributed throughout the year.

Rio Grande do Sul has a uniform and gentle undulating $620 \mathrm{~km}$ long barrier coast, oriented NE-SW and subject to dominant swell waves generated in southern latitudes and wind-generated waves produced by strong spring-summer sea breezes from the northeast. The average significant wave height is $1.5 \mathrm{~m}$ measured in water depths of $15-20 \mathrm{~m}$ (Motta 1969). During autumn and winter storms (April to July) wave height may frequently exceed $2.0 \mathrm{~m}$ and sea level can surge up to $1.3 \mathrm{~m}$ along the coast (Barletta and Calliari 2001, Calliari et al. 1998). The coast is microtidal with semidiurnal tides that have a mean range of only $0.3 \mathrm{~m}$. A net northward littoral drift is evident in coastal geomorphic features (Tomazelli and Villwock 1992), and confirmed by field measurements (Toldo-Jr. et al. 1993). Present day beaches of RS receive very little sand from inland, because most of the bedload carried by the few streams and rivers that drain to the coast is trapped in lagoons and other coastal plain environments (Tomazelli et al. 1998). According to Calliari and Klein (1993), beaches vary from dissipative to intermediate morphodynamic stages.

The Glacial-Postglacial sea level history of the Rio Grande do Sul coast extends from about $17.5 \mathrm{ka}$ when the sea level was about $120 \mathrm{~m}$ to $130 \mathrm{~m}$ lower (Corrêa 1995). After that time, sea level rose at an average rate of $1.2 \mathrm{~cm} / \mathrm{yr}$, but varying from $0.6 \mathrm{~cm} / \mathrm{yr}$ (14 to $12 \mathrm{ka}$ ) to $1.9 \mathrm{~cm} / \mathrm{yr}(8.0$ to $6.5 \mathrm{ka})$. There are no reliable data on sea-level behavior during Middle to Late Holocene time along the RS coast. However, sea-level curves for areas further to the north indicate that at the culmination of the Postglacial Marine Transgression (5.1 ka) sea level reached a few meters (2-3 m) above its present level, subsequently followed by a slow sea-level fall (Angulo and Lessa 1997). This general sea-level behavior also probably applies to the north coast of Rio Grande do Sul (Dillenburg 1996). The sea-level curve presented by Martin et al. (1979) indicates a maximum of $+5 \mathrm{~m}$ on the coast of Bahia State in NE Brazil, and evidence presented by Angulo and Lessa (1997) suggests that the maximum was around $+3.5 \mathrm{~m}$ in the States of São Paulo and Paraná to the north of RS. Angulo et al. (1999) suggest a maximum submergence of about $+2 \mathrm{~m}$ in nearby Santa Catarina State only $100 \mathrm{~km}$ to the north of RS (cf. Ybert et al. 2001).

Retrogradational barriers such as receded barriers and mainland beach barriers occur along coastal projections whereas progradational barriers occur in coastal embayments (Fig. 1; Dillenburg et al. 2000).

\section{BARrier Morphology and Type:}

Beach Ridges or Transgressive Dunefields?

Former studies of the Holocene barriers extending from just south of Torres (Itapeva) to south of Cassino have indicated that the barriers comprise both beach ridges and transgressive dunefields (Delaney 1963, Villwock 1984, Villwock and Tomazelli 1995). Transgressive dunefields are broad, aeolian sand deposits formed by the downwind movement of sand sheets and dunefields over vegetated to semivegetated terrain. They range from small sheets to large scale sand seas, and typically are bordered by precipitation ridges, and often fronted by deflation basins and plains (Hesp and Thom 1990). They may be unvegetated, vegetated to various degrees, or fully vegetated (relict). They are classified sep- 
arately from parabolic dunes because such dunes typically display a parabolic depositional lobe form, two trailing arms or ridges and a deflation basin or plain contained within the ridges (Hesp 1999).

In regard to the beach ridges, Delaney (1963) regarded the barrier extending from Torres to Tramandaí as comprising beach ridges. Villwock stated that there were "well preserved regressive beach ridges. . between Capão da Canoa and Torres" (Villwock 1984, p. 27), and Villwock and Tomazelli stated that there were "cordões litorâneos regressivos ("beach ridges')", to the north of Tramandaí (Villwock and Tomazelli 1995, p. 30). Dillenburg et al. (2000) state that the Holocene barrier is a beach/foredune ridge strand plain, with a narrow strip of transgressive dunes along the coastal margin. South of Tramandaí, active, modern, transgressive dunefields dominate the barrier morphology (Villwock and Tomazelli 1995, Dillenburg et al. 2000). Godolphim $(1983,1985)$ stated that the barrier south of Rio Grande and around Cassino comprised beach ridges. Barrier progradation started about 5000 years BP according to Dillenburg et al. (2000), but recent drilling indicates that the likely age of barrier initiation is around 7000-8000 years BP (Dillenburg et al. 2005).

Figure 4 shows a section of the Holocene barrier near Curumim which displays a morphology typical of much of the barrier system. The first few ridge lines present on the left side of the photograph are relatively straight or linear trending south-north. The seaward half of the barrier comprises ridges which are more irregular, discontinuous alongshore, and have crescentic and lobate morphologies. The active (white on the photograph) portion displays sets of discontinuous, triangularshaped dunefields with transverse and barchanoidal transverse dunes and separated by wash-outs (sangradouros; i.e. annual, seasonal and storm driven streams and creeks flowing out through the dunes; see da Silva et al. 2003). The inner ridges mostly appear to be parallel, regularly spaced ridges (and therefore approximate the form of 'beach ridges') on a large scale aerial photograph or satellite image.
However, measurement of ridge spacing shows that the ridges are on average spaced from 400 to $600 \mathrm{~m}$ apart on the landward half of the barrier, and 80 to $400 \mathrm{~m}$ apart on the seaward half of the barrier. They are therefore very widely spaced compared to most beach ridge or foredune plains (see below).

Generally only the landwardmost ridge adjacent to the lagoon has a pronounced ridge form, but on occasions, the next one or two seaward ridges may also display low (2-3 m), but obvious ridge forms. The landwardmost ridge is commonly a relatively high (up to $12 \mathrm{~m}$ ) narrow ridge with an asymmetric morphology and a steep lee slope commonly overlying lagoonal sediments. The ridge is therefore a precipitation ridge formed by sand saltating and falling into vegetation at the downwind margin of a transgressive dunefield (cf. Hesp and Thom 1990).

In the field, most of the remaining ridges are barely discernable, typically being only 0.5 to $\sim 1.0 \mathrm{~m}$ high above the gently undulating dunefields, or low-lying swampy plains lying to seawards. Most 'ridges' indicated on the photograph (Fig. 4) are not distinct convex ridge forms, but are the downwind, landward margins of broad, gently undulating, low, wide, sheets and dunefields which tend to dip seawards. The 'ridges' are thus low precipitation ridges and the low angle terminal margins of dunefields.

The 'ridges' forming the seaward half of the barrier are more irregular, lobate forms. These landforms do not look similar to typical foredune or beach ridges in plan view or cross-section (see below). Rather they mimic the landward marginal morphology of the active dunefield which also displays an irregular, discontinuous, lobate form. The modern dunes are not continuous alongshore because they are cut by regularly spaced wash-outs (sangradouros). The vegetated dunes have had similar histories and are discontinuous alongshore because they have also been cut by wash-outs in the past. Many palaeo-washouts can be observed across the seaward half of the barrier and commonly link to the current active washouts.

The dunes are pock-marked or have multiple 


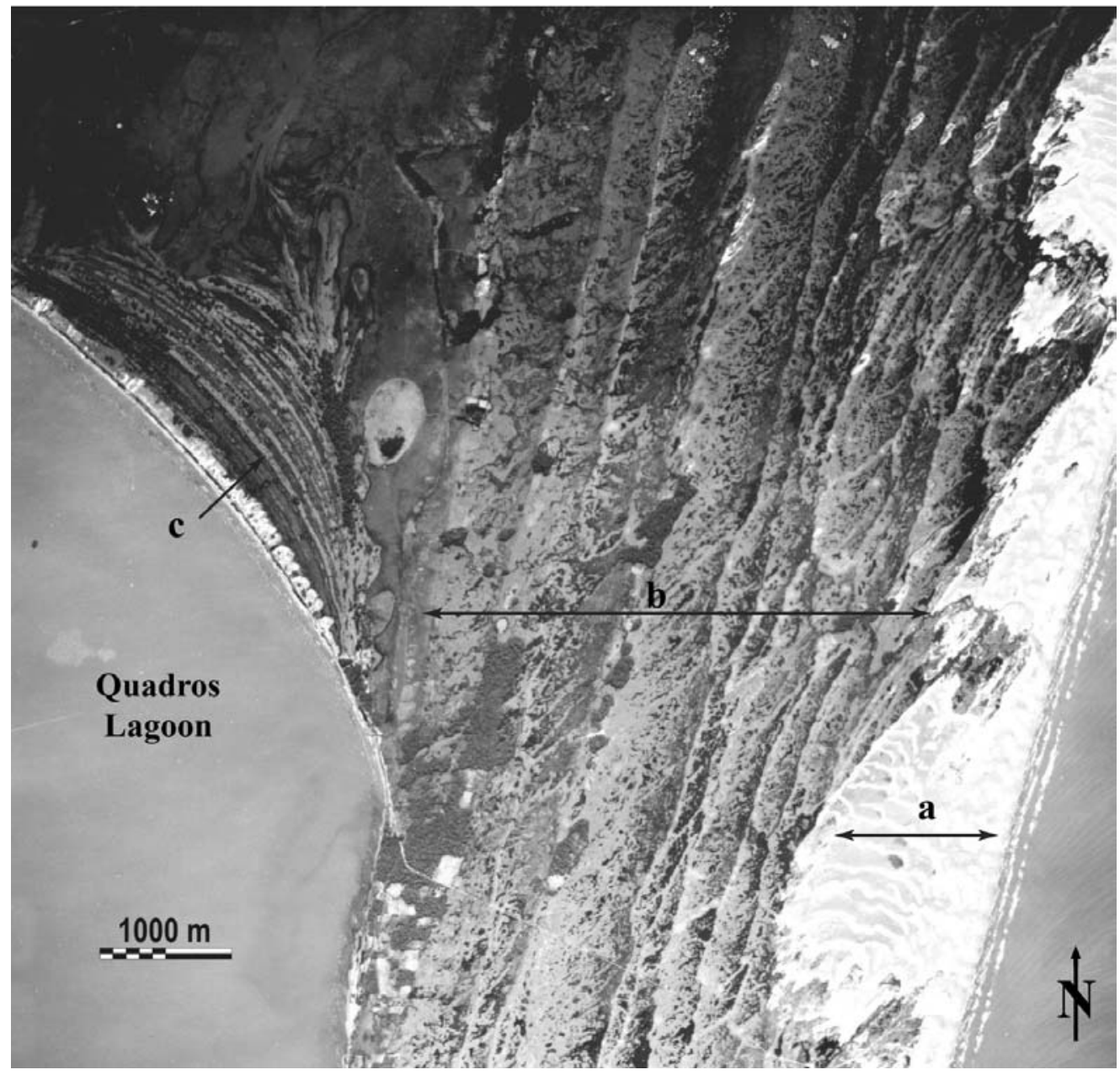

Fig. 4 - The Holocene transgressive dunefield prograded barrier system at Curumim, $\sim 150 \mathrm{~km} \mathrm{NE}$ of Porto Alegre. The seaward portion is an active transgressive dunefield (a), while the vegetated portion consists of many overlapping, low, vegetated transgressive dunefields (b). This barrier has been interpreted in the past as a 'beach ridge plain' but the ridge lines are actually precipitation ridges and the terminal margins of dunefields marking the downwind edge of each dune phase. Many ridges on the seaward half of the barrier are lobate and not laterally continuous, and have been eroded, or terminated by wash-outs (sangradouros). The spacing between ridges is hundreds of meters, far greater than that observed for foredunes or beach ridges (sensu stricto). In contrast, note the scale, ridge spacing and plan shape of the beach ridges and foredunes which occur on the northeastern margin of the Quadros Lagoon at Arroio Cornelius (c).

dimples (pequenas cavidades or pequenas depressões; Houaiss 1982). These are multiple, irregularshaped ponds and swamps and generally have alignments which are NE-SW. They are former small deflation ponds and form within the extensive, low, swampy sand plains and nebkha fields which lie between each 'ridge' line. Nebkhas are formed where discrete plants trap sand forming iso- lated hummocks.

Examination of trenches and sections within the landward half of the dunefield at "Green Village" near Xangri-lá, and near Currumin indicates that the dunes are also relatively low, forming wide dune sheets and undulating dunefields. In a few places, flat to slightly undulating palaeosols are present. Their position and extent indicates alternat- 
ing phases of dune stabilization and sand inundation, and occasional downwind movement of dunes over older dune fields or sheets. No regular, smaller scale, ridge and swale palaeosols or morphologies such as those normally seen in beach ridge or foredune plains can be observed.

In addition, if the present is a key to interpreting the past, then the modern, active transgressive dunefield should represent the current active phase, and one stage in the development of multiple phases of transgressive dunefields (now vegetated) formed over the last 6000 to 7000 years.

In comparison to the 'ridges' shown on Figure 4 , foredune ridge crests in a foredune plain are typically spaced around 5 to $30 \mathrm{~m}$ apart (depending on rate of progradation). They display intervening shallow to relatively deep swales $(\sim 1$ to $\sim 8 \mathrm{~m}$ below the ridge crests), and are arranged in closely spaced sets that are usually continuous alongshore and generally follow the former beach outline in plan view. They range from very regular, symmetrical, morphologically and topographically simple shapes where beach and dune stability is high (e.g. Fig. 3), to more asymmetrical dune ridges with variable heights alongshore and with relict blowouts where stability is, or has been lower.

Beach ridges (sensu stricto) tend to have similar spacing to foredunes where progradation is slow, or storms and high water levels are common. However, ridge spacing is much wider where progradation is more rapid, and beach ridges are separated by wide, flat to slightly concave swales formed during normal water level conditions, or where storm activity and high water levels are less common. For example, photographic surveys at Arroio Cornelius on the Quadros Lagoon show that ridge spacings are around 50-60 m (Fig. 4). These ridges (and occasional capping foredunes) are separated by wide, relatively flat swales often infilled with organic sediments. Internal structures of the beach ridges are markedly different than foredunes or transgressive dunes (Fig. 2b). Both beach ridges and foredunes are typically straight, parallel, and continuous alongshore.

\section{The Barriers South of Tramandaí}

The barrier continues south from Tramandaí to the northern jetty at the entrance of Patos Lagoon (Lagoa dos Patos) but is dominated by active transgressive dunefields, and the earlier phases of dunefield development can only be again observed south of $\sim$ Estreito. The barrier to the south of Rio Grande is initially a complex barrier comprising sets of foredunes (not beach ridges) and transgressive dunefield phases, and becomes a transgressive dunefield barrier again south of around Verga Lighthouse (Fig. 1).

\section{CONCLUSIONS}

1. Beach ridges should be morphodynamically and genetically distinguished from berms and foredunes.

2. A berm is here defined as a shore parallel, nonpersistent wave built ridge or terrace formed by swash and wave processes between the low tide level and the limit of swash runup.

3. Beach ridges are here re-defined as swash aligned, swash and storm wave built deposits or ridges formed primarily of sand, pebbles, cobbles or boulders, or a combination of these sediments. They may also contain various amounts of other marine and organic sediments (e.g. shell, pumice, wood). They are typically formed at, or above the normal spring high tide level and are generally persistent. They are purely or principally marine deposits formed by wave action.

4. The barrier extending from Itapeva to Tramandaí displays a range of characteristics and landforms very different from typical beach ridges including: relatively straight (inner portion) and conspicuously cuspate (outer portion) precipitation ridges and terminal margins that are very widely spaced. Wide, low, swampy sand plains and sheets, nebkha fields and deflation plains; multiple, pequenas depressões; palaeo- and active washouts, and, marginal, active, modern transgressive dunefields. 
5. The Itapeva to Tramandaí barrier system is not a beach ridge plain or "planície de cordões litorâneos regressivos", but is, in fact, a prograded, transgressive dunefield barrier, created by the multiple formation of transgressive dunefield phases. The majority of the transgressive dunefields are now fully vegetated, and the modern active transgressive dunefield is merely the latest phase of a suite of phases which have occurred since the beginning of barrier progradation around 7000 or more years ago.

\section{ACKNOWLEDGMENTS}

This paper was written while Patrick Hesp held a visiting fellowship at Centro de Estudos de Geologia Costeira e Oceânica (CECO), UFRGS. Patrick sincerely thanks Sergio Dillenburg, Ricardo AyupZoauin and Luiz Tomazelli for their financial and field support, Eduardo Barboza for technical support, and all the CECO team for their assistance in the field, friendship and many discussions on dunes. Sérgio R. Dillenburg, Luiz J. Tomazelli and Elírio E. Toldo Jr. thank the Conselho Nacional de Desenvolvimento Científico e Tecnológico (CNPq) for the provision of their research fellowships. We also thank the Pro-Reitoria de Pesquisa - UFRGS for partial financial support, and three anonymous reviewers for substantially improving the manuscript.

\section{RESUMO}

Muitas barreiras progradantes e alguns campos de dunas têm sido chamadas de planícies de cordões de praia ("beach ridge plains"), embora a sua gênese seja ainda discutível. O uso dos termos berma, cordão de praia e dunas frontais é também confuso na literatura, pois suas definições são muito variáveis e são comumente usados de uma maneira intercambiável. Portanto, a formação e definição de bermas de areia, cordões de praia e dunas frontais são brevemente revisadas. Os cordões de praia são redefinidos como depósitos integralmente formados por ondas e que são, na maioria das vezes, formados durante condições de alta energia de ondas e/ou níveis de água elevados (e.g. elevação do nível de água durante tempestades). Dunas frontais são formadas por deposição eólica de areia na vegetação de pós-praia. Alguns campos de dunas no Brasil têm sido chamados de planícies de cordões de praia, quando na verdade eles são planícies de dunas frontais, campos de dunas transgressivas, ou barreiras complexas (i.e. barreiras mostrando os dois tipos de dunas). Um destes campos de dunas ocorre na barreira holocênica existente entre Torres e Tramandaí no sul do Brasil. As características morfológicas desta barreira se apresentam na forma de largos, relativamente retilíneos e largamente espaçados (400-600m) cordões paralelos à linha de praia, na metade interna (no sentido do continente) da barreira, e na forma de menos espaçados (80-400m), com forma lobada e crescente, e mais discretos cordões na metade externa da barreira. Baixos e ondulados campos de dunas, lençóis de areia, dunas do tipo "nebkhas" e planícies de deflação ocorrem entre os cordões. A barreira é reinterpretada como uma barreira de dunas transgressivas progradante.

Palavras-chave: cordões de praia, barreiras costeiras, dunas transgressivas, Holoceno, sul do Brasil.

\section{REFERENCES}

ANGulo RJ. 1993. Morfologia e gênese das dunas frontais do litoral do estado do Paraná. Rev Bras Geocienc 23: 68-80.

Angulo RJ And Lessa GC. 1997. The Brazilian sea level curves: a critical review with emphasis on the curves from Paranaguá and Cananéia regions. Mar Geol 140: 141-166.

Angulo RJ, Giannini PCF, Suguio K and Pessenda LCR. 1999. Relative sea-level changes in the last 5500 years in southern Brazil (Laguna-Imbituba region, Santa Catarina State) based on vermetid ${ }^{14} \mathrm{C}$ ages. Mar Geol 159: 323-339.

Armstrong Price W. 1982. Beach ridge plain. In: Schwartz ML (Ed), The Encyclopaedia of Beaches and Coastal Environments. Encyclopedia of Earth Sciences, Stroudsburg: Hutchinson Ross Publishing Company, p. 159-160.

Barletta RC And CAlliari LJ. 2001. Determinação da intensidade das tempestades que atuam no litoral do Rio Grande do Sul, Brasil. Pesquisas em Geociências 28: 117-124.

BIRD ECF. 1960. The formation of sand beach ridges. Aust J Sci 22: 349-350.

BIRD ECF. 1976. $2^{\text {nd }}$ ed. Coasts. An Introduction to Coastal Geomorphology. ANU Press, 320 p. 
BIRD ECF. 2000. Coastal Geomorphology an Introduction. J Wiley \& Sons, 322 p.

BrookfIEld ME. 1992. Eolian Systems. In: WALKer RG AND James NP (Ed), Facies Models Response to Sea Level Change. Geolog Assoc of Canadá, p. 143-156.

CAlliari LJ ANd Klein AHF. 1993. Características morfodinâmicas e sedimentológicas das praias oceânicas entre Rio Grande e Chui, RS, Brasil. Pesquisas 20: 48-56.

Calliari LJ, Tozzi HAM and Klein AHF. 1998. Beach morphology and coastline erosion associated with storm surges in southern Brasil - Rio Grande to Chui. In: LAND-OcEAN INTERCATIONS IN THE COASTAL Zone (LOICZ) Meeting. An Acad Bras Cienc 70: 231-247.

CARTER RWG. 1986. The morphodynamics of beach ridge formation: Magilligan, Northern Ireland. Mar Geol 73: 192-214.

Carter RWG and Wilson P. 1990. The geomorphological, ecological and pedological development of coastal foredunes at Magilligan Point, Northern Ireland. In: Nordstrom K, Psuty N ANd Carter RWG (Eds), Coastal Dunes: Processes and Morphology, Chichester. J Wiley \& Sons, p. 130-157.

CORRÊA ICS. 1995. Les variations du niveau de la mer durant les derniers 17.500 ans BP: l'exemple de la plateforme continentale du Rio Grande do Sul-Brésil. Mar Geol 130: 163-178.

Curray JR, Emmel FJ and Crampton PJS. 1969. Holocene history of a strand plain, lagoonal coast, Nayarit, Mexico. In: Castanares AA ANd PhleGER FB (Eds), Lagunas Costeras, un Simposio (Coastal lagoons, a Symposium). Mexico, UnamUnesco, 1967, p. 63-100.

DAVIES JL. 1957. The importance of cut and fill in the development of sand beach ridges. Aust J Sci 20: 105-111.

Davies JL. 1980. Geographical Variation in Coastal Development, Longman, London, 212 p.

DELANEY PJV. 1963. Quaternary geologic history of the coastal plain of Rio Grande do Sul, Brazil. Louisiana State University Studies, Coastal Studies Series no. 7, Louisiana State University Press, 63 p.

Dillenburg SR. 1996. Oscilações Holocênicas do Nível Relativo do Mar Registradas na Sucessão de Fácies
Lagunares na Região da Laguna de Tramandaí, RS. Pesquisas em Geociências 23: 17-24.

Dillenburg SR, Roy PS, Cowell PJ AND Tomazelli LJ. 2000. Influence of antecedent topography on coastal evolution as tested by the Shorface Translation-Barrier Model (STM). J Coast Res 16: 71-81.

Dillenburg SR, Tomazelli LJ, Hesp PA, Barboza EG, Clerot LCP And Silva DB. 2005. Stratigraphy and evolution of a prograded, transgressive dunefield barrier in southern Brazil. J Coast Res SI 39 (in press).

Godolphim MF. 1983. Contribuição ao estudo da evolução da Barra do Rio Grande, Brasil. Pesquisas 15: $22-43$.

GodolPhim MF. 1985. Paleogeografia da Região do Cassino no Município de Rio Grande, Brasil. Pesquisas 17: 233-254.

Guilcher A. 1958. Coastal and Submarine Morphology. London, Methuen and Co., 274 p.

Hesp PA. 1983. Morphodynamics of incipient foredunes in N.S.W., Australia. In: BRookfIELd ME AND AHLBRANDT TS (Eds), Eolian Sediments and Processes, Elsevier, p. 325-342.

Hesp PA. 1984a. The formation of sand 'beach ridges' and foredunes. Search 15: 289-291.

Hesp PA. 1984b. Foredune formation in Southeast Australia. In: Tном BG (Ed), Coastal Geomorphology in Australia. Academic Press, p. 69-97.

Hesp PA. 1999. The Beach Backshore and Beyond. In: SHorT AD (Ed), Handbook of Beach and Shoreface Morphodynamics, Chichester. J Wiley \& Sons, NY, p. $145-170$.

Hesp PA. 2000. Coastal Dunes. Forest Research (Rotorua) and NZ Coastal Dune Vegetation Network (CDVN), $28 \mathrm{p}$.

HesP PA. 2002. Foredunes and Blowouts: initiation, geomorphology and dynamics. Geomorphology 48 : $245-268$

Hesp PA AND Thом BG. 1990. Geomorphology and evolution of transgressive dunefields. In: NoRDStrom K, Psuty N ANd CARTER RWG (Eds), Coastal Dunes: Processes and Morphology, Chichester. J Wiley \& Sons, p. 253-288.

Hine AC. 1979. Mechanisms of berm development and resulting beach growth along a barrier spit complex. Sedimentology 26: 333-351. 
Houaiss A. 1982. Dicionário Inglês-Português. Record, Rio de Janeiro, RJ, Brasil, 925 p.

JoHnson DW. 1919. Shore Processes and Shoreline Development. J Wiley \& Sons, 584 p.

KING CAM. 1972. Beaches and Coasts. Edward Arnold, London, $570 \mathrm{p}$.

Komar PD. 1976. Beach Processes and Sedimentation, Prentice-Hall, Englewood Cliffs, 429 p.

LAw M And Davidson-Arnott R. 1990. Seasonal controls on aeolian processes on the beach and foredune. In: Canadian Coastal Conference on Coastal SAND DunES. p. 49-68.

Martin L, Flexor JM, Vilas Boas GS, Bittencourt ACSP And Guimaraes MMM. 1979. Courbe de variations du niveau relative de la mer au cours des 7000 dernières années sur un secteur homogène du littoral brésilien (nord de Salvador, Bahia). In: INTERNATIONAL Symposium ON COASTAL Evolution IN THE QuATERnARY. São Paulo, SP, Brazil, p. 264274.

Masselink G And Short AD. 1993. The effect of tide range on beach morphodynamics. A conceptual beach model. J Coast Res 9: 785-800.

McKenzIE P. 1958. The development of sand beach ridges. Aust J Sci 20: 213-214.

Мотта VF. 1969. Relatório Diagnóstico Sobre a Melhoria e o Aprofundamento do Acesso pela Barra do Rio Grande. Instituto de Pesquisas Hidráulicas, UFRGS, Porto Alegre, RS, Brasil, 144 p.

Olson JS. 1958. Lake Michigan dune development 2. Plants as agents and tools in geomorphology. J Geol 66: 345-351.

Oтvos EG. 2000. Beach ridges - definitions and significance. Geomorphology 32: 83-108.

Psuty NP. 1965. Beach-ridge development in Tabasco, México. Annals Assoc Amer Geog 55: 112-124.

Redman JB. 1864. The east coast between the Thames and the Wash estuaries. Minutes of the Proceedings of the Institution of Civil Engineers 23: 186-257.

Reineck H-E And Singh IB. 1986. Depositional Sedimentary Environments. Springer Verlag $2^{\text {nd }}$ ed., $551 \mathrm{p}$.

Ruz M-H and Allard M. 1994. Coastal dune development in cold climate environments. Physical Geography $15: 372-380$.
SAlisbury E. 1952. Downs and Dunes: Their Plant Life and Environment. G. Bell, London, UK, 328 p.

SARRE R. 1989. The morphological significance of vegetation and relief on coastal foredune processes. Zeit Für Geomorph NF Suppl-Bd 73: 17-31.

SHORT AD. 1999. Wave-dominated beaches. In: SHORT AD (Ed), Handbook of Beach and Shoreface Morphodynamics, Chichester. J Wiley \& Sons, NY. p. 173-203.

Silva RP, Calliari LJ and Tozzi HaM. 2003. The influence of washouts on the erosive susceptibility of the Rio Grande do Sul coast between Casino and Chui Beaches, Southern Brazil. J Coast Res SI 35: 332-338.

STAPOR FW. 1982. Beach ridges and beach ridge coasts. In: SchwARTz ML (Ed), Encyclopaedia of Beaches and Coastal Environments. Hutchinson Ross, Stroudsburg, p. 160-161.

TANner WF AND Stapor FW. 1971. Tabasco beachridge plain: an eroding coast. Trans Gulf Coast Assoc Geol Soc 21: 231-232.

TANner WF ANd Stapor FW. 1972. Precise control of wave run-up in beach ridge construction. Zeit Für Geomorph 16: 393-399.

TAYlor M And Stone GW. 1996. Beach ridges: A review. J Coast Res 12: 612-621.

Thom BG, Bowman GM AND Roy PS. 1981. Late Quaternary evolution of coastal sand barriers, Port Stephens - Myall Lakes area, central New South Wales, Australia. Quat Res 15: 345-364.

Toldo-Jr EE, Dillenburg SR, Almeida LES, TabaJARA LL, Martins RR AND Cunha LOBC. 1993. Parâmetros Morfodinâmicos da Praia de Imbé, RS, Brasil. Pesquisas em Geociências 20: 27-32.

Tomazelli LJ AND Villwock JA. 1992. Considerações Sobre o Ambiente Praial e a Deriva Litorânea de Sedimentos ao Longo do Litoral Norte do Rio Grande do Sul, RS, Brasil. Pesquisas em Geociências 19: 3-12.

Tomazelli LJ, Villwock JA, Dillenburg SR, Bachi FA AND Dehnhardt BA. 1998. Significance of present-day coastal erosion and marine transgression, Rio Grande do Sul, southern Brazil. An Acad Bras Cienc 70: 221-229.

UL'st VG. 1957. Morphology and developmental history 
of the region of marine accumulation at the head of Riga Bay. Akademiva Nauk Latviskoi SR, 179 p.

Viles H. 1988a. Berm. In: Goudie A, AtKinson BW, Gregory KJ, Simmons IG, Stoddart DR, SugDEN D (Eds), The Dictionary of Physical Geography, Blackwell, $47 \mathrm{p}$.

Viles H. 1988b. Beach ridge. In: Goudie A, AtKinSON BW, Gregory KJ, Simmons IG, STODDART DR, Sugden D (Eds), The Dictionary of Physical Geography, Blackwell, $45 \mathrm{p}$.

VILLWOCK JA. 1984. Geology of the coastal province of Rio Grande do Sul, southern Brazil. A Synthesis. Pesquisas 16: 5-49.
Villwock JA AND Tomazelli LJ. 1995. Geologia Costeria do Rio Grande do Sul. Notas Técnicas 8: 1-45.

Villwock JA, Tomazelli LJ, Loss EL, Dehnhardt EA, Horn Fo. NO, Bachi FA and DehnhardT BA. 1986. Geology of the Rio Grande do Sul coastal province. In: RABASSA J. (Ed), Quaternary of South America and Antarctic Peninsula, Rotterdam, Netherlands. A.A. Balkema 2: 79-97.

Ybert J-P, Bissa WM and Kutner M. 2001. Relative sea level variations and climatic evolution in southeastern and southern Brazil during the late Holocene. Pesquisas em Geociências 28: 75-83. 